УДК 572

Васильєва Л. А.

doi: 10.32620/gch.2018.4.02

\title{
«ЛЮДИНА ПУБЛЮЧА» ЯК ДЕМОСТРАТИВНИЙ СИМВОЛ КОМУНІКАТИВНОГО ПРОСТОРУ
}

У статті осмислено буттєвість багатовимірної природи сучасного феномена «людини публічної». Доведено, що людина, залучена до публічного життя, є відкритою самобутньою системою. При иьому натепер значним є те, щзо самобутність людської самості периочергово актуалізується демонстративною функиією публічного середовища й через новітні техніки й технології відкрито апелює до безмежних людських бажань $i$ потреб, створюючи тотальне комунікативне середовище успішності ци особистісної значущості.

Ключові слова: публічність, тілесність, толерантність, «людина публічна», тіло, імідж, репутація, самість, публічне буття.

In this article, the exuberance of the multidimensional nature of the modern phenomenon of «public person» is conceptualized. The author argues that a person included in public life is a unique and open system. However, it is important to take into consideration that diversity of the human identity has to be actualized by the demonstrative function of the public environment and, by means of modern technologies and techniques it openly appeals to the formation of boundless human desires and needs by creating the communicative environment of success and personal significance.

Keywords: publicity, corporeality, tolerance, «public person», body, image, reputation, the self, public existence.

В статье осмысливается бытие многомерной природы современного феномена «человека публичного». Доказывается, что человек, включенный в публичную жизнь, является открытой самобытной системой. При этом значимым является тот факт, что самобытность человеческой самости в настоящее время в первую очередь актуализируется демонстративной функцией публичной среды и через новейшие техники, технологии открыто апеллирует к формированию безграничных человеческих желаний и потребностей, создавая особую коммуникативную среду успешности и личностной значимости.

Ключевые слова: публичность, телесность, толерантность, «человек публичный», тело, имидж, репутация, самость, публичное бытия.

Людина публічна в умовах розширення меж сучасного публічного простору повсякчас має можливість легко демонструвати себе як значущий «товар» (Е. Фром), неупереджено й активно змінюючи себе як на фізичному, так і на духовному рівнях, швидко адаптуючись до запитуваних публічністю моделей особистої презентації. При цьому iï прихована самобутність не викликає значного соціального інтересу, залишаючись незрозумілою, а значить, і не цікавою масовому «глядачеві».

Основною метою статті є осмислення буттєвості багатовимірної природи сучасного феномена «людини публічної». 
Наявні наукові роботи щодо феномена публічності лише підкреслюють синтетичність й амбівалентність характеристик феномена «людини публічної», виявляючи дуальність цього явища через поєднання штучності й природності. Серед дослідників, які прямо чи опосередковано зверталися до питань публічності, слід виділити Х. Арендт, Ф. Ар’єса, К.-О. Апеля, М. Бубера, С. Бенхабіб, Дж. Вайнтрауба, Ю. Габермаса, Е. Гуссерля, П. Вірно, Д. Вольтона, Дж. Ван Дейка, Р. Дойча, У. Ліпмана, Г. Лебона, Х. Ортегу-і-Гассета, В. Парето, Р. Сеннета, Я. Щепаньского, К. Ясперса. Серед українських дослідників слід відзначити С. Бордунову, М. Грищенко, О. Жулькевську, О. Злобіну, Л. Малеса, А. Петренко-Лисак, В. Середу, I. Тищенко, Л. Радіонову та ін. На сторінках робіт цих авторів можна прослідкувати думку, що, з одного боку, явище публічності - це спеціально спроектоване й сконструйоване комунікативне середовище, а 3 другого - середовище непередбачуване, оскільки його об’єктом є людська свідомість, яка намагається володіти вільною реакцією залежно від ціннісно-цільових настанов суб'єктів.

Безперечно, у сучасному публічному середовищі людина публічна через постійну доступну залученість у відкритий технічно насичений соціальний простір максимально швидко й ефективно впроваджує форми своєї успішної презентації, значущості й соціальної активності. Чи несе це в собі негативну складову? Однозначно відповісти на таке питання дуже складно, оскільки ще Ж.-П. Сартр усередині XX ст. писав: «Людина - істота, яка звернена до майбутнього й усвідомлює, що саме вона проектує себе в майбутнє. Людина - це насамперед проект, який переживається суб'єктивно, а не мох, пліснява й не цвітна капуста. Нічого не існує до цього проекту, немає нічого в загадкових небесах, і людина стане такою, який iï проект буття» [12, с. 320]. Із другого боку, ураховуючи сучасну трансформацію сфери публічності в запитувано-масовий престижний простір, де людське життя набуває сенсу лише завдяки реалізації власного публічного проекту самопроектування, формується популярна культура прозорого гламурного стилю життя й підкресленого інтелектуального / маргінального публічного індивідуалізму, публічність при цьому набуває спотворених штучних форм. Через таку прозоровідкриту культуру людина публічна набуває для себе начебто яскравого самовираження, свободи, звільняється від соціального тиску й обмежень, що існували в традиційному модерністському суспільстві. Стиль життя «на очах» - це спосіб самотворення, набуття автентичності, апробації різних варіантів власного «Я» через надмірну відкритість і демонстративність, так звану можливість бути самим собою. Це спосіб звільнення в тому розумінні, яке притаманне різним формам і проявам масового бунту. Але чи здатна масовість формувати самість, ідентичність й істину унікальність?

Цікавим є те, що саме на межі XX-XXI ст., коли людина вирішила підкорити собі техніку, матерія, у тому числі й жива, починає розглядатися як засіб передання інформації, а тіло людини - як код, технічний конгломерат знаків. Саме тому в теперішніх умовах знакова система публічності переповнюється прагненнями відкритої демонстрації кодів молодості й шику, формуючи активну публічну систему комунікативної взаємодії. Саме тепер гарне тіло, що часто обігрується в рекламі як 
вагома компонента успішності, уже не несе в собі лише естетичну наповненість. Така відкрита тілесність стає демонстративним символом здоров'я, сили, молодості, матеріального добробуту, влади, будучи по суті «зоровим наркотиком», що обіцяє щастя. «Я просто стояла й дивилась ролик разів п'ять, напевно, аби тільки подивитися на модель довше, ... на продукти я й уваги не звертала. Просто думала, що переді мною вражаючі люди, які виглядають дуже... ефектно», - так говорить одна 3 героїнь сучасного американського письменника Теда Чана у фантастичному творі «Тобі подобається те, що ти бачиш?» [14]. У цьому оповіданні автор через художне слово розкриває соціальну проблему дискримінації за зовнішніми параметрами, що нав'язується самим масовим суспільством як сучасні ціннісні пріоритети. Т. Чан припускає неймовірну думку про так звану «каліагнозію» - механічний пристрій, здатний «умикати-вимикати» людську реакцію на красу. «Уважайте каліагнозію свого роду прищепленою зрілістю. Вона дозволяє вам робити те, що, як ви й самі знаєте, варто робити: не звертати увагу на зовнішнє, щоб зазирнути глибше» [14, с. 5].

Посилаючись на вищесказане, слід підкреслити, що сучасне розуміння краси в публічному просторі значно відрізняється від класичних канонів естетики, набуває іноді найрадикальніших форм, сприяє естетизації культу штучної краси. Звісно, слід розмежувати такі поняття, як «краса» й «прекрасне», відзначаючи, що у своєму естетичному сприйнятті поняття краси досить близьке до поняття прекрасного 3 тією лише різницею, що останнє є вищим (абсолютним) ступенем краси [8, с. 464]. Специфікою інтерпретації краси у філософії класичного типу $\epsilon$ принципово позаемпіричне іï розуміння й віднесення до трансцендентного початку: «Якщо прекрасне - одна із сутнісних модифікацій естетичного, тобто характеристика суб'єкт-об'єктних відносин, то краса, як показує досвід історико-естетичного дослідження, - категорія, що входить у сутнісне поле прекрасного i $\epsilon$ характеристикою тільки естетичного об'єкту» [4, с. 196]. Поняття «краси», що у філософському науковому середовищі обговорювалося неодноразово [6; 9; 10; 13], здобуває безліч трактувань. У повсякденному розумінні трактується як зовнішня привабливість і сприймається людиною інстинктивно. Існує думка, що така краса закріплюється в пам'яті людини завдяки минулим поколінням із їхнім несвідомим досвідом. Крім того, варто принципово відрізняти поняття краси від красивості, оскільки поняття красивості спирається тільки на систему поверхових формальних характеристик об'єкта, детермінованих віяннями смаку й моди, на сприйняття ж краси впливають історичні, соціальні, національні, культурні, релігійні, антропні й інші параметри суб'єкта сприйняття.

У сучасних умовах інформаційної перенасиченості гарне тіло стає посередником, який пов’язує людське «Я» 3 соціально-публічним середовищем соціуму, формує образ, імідж людини: «Антропологія тіла - це вчення про культуру й культурні процеси, які розглядають як у-тілення» [17, с. 18]. Тіло як інструмент передавання змісту набуває актуальності насамперед у зв’язку з посиленням уваги до філософського аналізу тілесних практик. У сьогоденні тіло - інструмент виявлення думок, почуттів. Засіб навчитися говорити тілом найяскравіше проявився в пластичних мистецтвах. Ця ідея втілилися в театрі авангарду А. Арто, у німому кіно, 
у пантомімах тощо. «Тілесний театр» французького письменника, драматурга, актора А. Арто грунтується на домінанті використання тіла як інструмента відтворювання думок і почуттів, що з тих чи інших причин заблоковані цензурою різних культурних традицій та умовностями соціуму. У «тілесному театрі» думка народжується й живе за допомогою пластики тіла як інструмента. Жест - це ієрогліф тіла й соціального організму. Будь-який рух людського тіла є його своєрідною мовою, яка закодована в ієрогліфі та має власне значення. Тілесний образ розглядають як інтуїцію або миттєве знання про своє тіло, співвідношення його рівних частин між собою й особливо у його зв'язках із публічністю. Досвід «тілесного театру» А. Арто доводить, що тіло $є$ тим публічним інструментом, що створює своєрідну мову, за допомогою якої можна публічно передати найпотаємніші нюанси людського духу.

Сучасна актуалізація тіла - це актуалізація його демаркації, у якій низка позначок і знаків розчленовують його як даність, реконструюючи як структурний матеріал для знакового обміну. У такий спосіб тіло з позначкою відрізняється від тіла без позначки. Соціально маркована частина тіла, з одного боку, висувається на перший план як пафосний експонат демонстрації, а 3 другого $-\epsilon$ свідченням символічного прихованого змісту, який обов'язково має бути визнаний публічно. Так, завдяки допоміжним засобам (позначкам), якими є макіяж, татуювання, пірсинг, зачіска, манікюр, одяг, ювелірні прикраси тощо відбувається своєрідне подвоєння відповідної частини тіла й перетворення ㄲï на еротичну зону, на фетиш, який може стати предметом публічного самоототожнення: «Суб'єкт не спрощує себе в акті обміну - він спекулює. Саме він, а не дикун, перебуває у стані повного фетишизму: перетворюючи на цінність своє тіло, він і сам фетишизується законом цінності» [3, c. 203]. Специфічним у цьому випадку є те, що біологічне й живе під впливом ряду зовнішніх імперативів (гламуризації) мімікрують під синтетичне й штучне.

Накладання тілесності на знаково-символічний простір публічності за сучасних умов функціонування ринково-інформаційного суспільства зумовлює виникнення феномена володіння тілом, який свідчить про нівеляцію таких аспектів актуалізації тілесності, як невимушеність, щирість, природність і відвертість самоусвідомлення: «При орієнтації на володіння нема живого зв'язку між мною й тим, чим я володію. I об'єкт мого володіння, і я перетворилися на речі, і я володію об'єктом, оскільки у мене є сила, щоб зробити його моїм. Але тут має місце й зворотній зв'язок: об'єкт володіє мною, тому що моє почуття ідентичності, тобто психічне здоров'я, засноване на моєму володінні об'єктом (і якомога більшою кількістю речей). Такий спосіб існування встановлюється не посередництвом живого, продуктивного процесу між суб'єктом і об'єктом; він перетворює на речі і суб'єкт, і об'єкт. Зв'язок між ними смертоносний, а не животворчій» [16, с. 103-104].

На сучасному етапі завдяки публічному посередництву тілесність фігурує в символічному просторі знака, створюючи в такий спосіб безліч варіантів самоінтерпретації, а «відчуження від себе у наслідуванні образу знижує самість, зменшує життя тіла, яке починає слугувати образу, а значить, відчужує людину від реальності свого тіла, без чого неможливе відчуття реальності світу» [7, с. 191]. У такий спосіб людина може втратити зв'язок із реальністю, наділяючи власне буття 
віртуальним змістом. Так, на позначення процесу самоідентифікації українська дослідниця Л. Газнюк уводить поняття «сома»: «Сома - це «Я сам», «Я», як тілесна істота, в якій тіло - це річ, яку я маю, яка мені належить поряд 3 іншими речами навколишнього світу, тобто тіло - це наочна даність, переважно просторова. Сома ж це онтологічна сутність, чуттєво-екзистенційна, темпоральна категорія. Таке розуміння соми дає підстави розглядати соматичне буття як стан людської тілесності i персональний модус особистості, де поєднується емпірична предметність і духовна суб' єктивність» [5, с. 3-4].

Професор Г. Фезерстоун [18] підкреслює, що в сучасній культурі публічного споживання виникла нова особистісна концепція «самопросування», яка ставить на перший план зовнішній вигляд, демонстративність і керування думками оточення. Живий організм і середовище при цьому перебувають у системній єдності. Якщо шукати щось на кшталт роздільної лінії, то все живе, на думку Г. Плеснера [11], переносить усередину організму й зміщує ту межу, що відокремлює індивіда від середовища. У людини ця межа підлягає ще одній зміні - у цьому центрі послаблюється «Я», яке керує іiї самістю. Енергетично й речовинно світ пронизує все соматичне буття людини. Неорганічна тілесність, яку створює людина, може провокувати появу в органічній плоті органів, про які сучасна наука ще нічого не знає [15].

Демонстративну публічність можна осмислювати через соціокультурні прояви «естетизації публічного життя», що стосуються естетичних або культурних цінностей і формують окремі культурні ресурси й публічний капітал. Як зазначає 3. Бауман, проектування себе - це вже не предмет самостійного вибору, а особливість публічного життя: «Сучасність замінює гетерономне визначення соціального стану обов'язковим самовизначенням» [2, с. 153]. Тобто, якщо особа хоче самоствердитись у сучасному швидкоплинному світі, сповненому ситуаціями ризику, невизначеності й масовості, їй необхідно навпаки відсторонитися від гіперактивного й відкритого «життя на очах», а сконцентруватися на культурі публічного індивідуалізму й через власну репутацію й цінісно-нормативі принципи, які грунтуються на загальнолюдських цінностях час від часу, доводити своє значення, перш за все, у міжособистісному спілкуванні. Тут окремого статусу набуває й ділова етика, i готовність самої аудиторії слухати й бачити, і морально-культурні виміри кожної окремої людини.

Таким чином, не через демонстративність, а через занурення в ціннісний ресурс окремої людини можливо досягти потрібної істинної публічності без агресії й конфронтації. Тільки долаючи особистісні недоліки (слабкість, поверховість, егоцентризм), можна побудувати необхідне для виживання толерантне публічне середовище, вагоме для більшості.

Саме репутація, а не демонстративна імідж-публічність має виходити на перший план у формуванні знання про людину публічну. Демонстративна імідж-публічність це лише образна мозаїка надуманої власної ідентичності, що активно виставляється на суд соціального оточення та $є$ простим й зручним засобом побудови бажаної особистісної ідентифікації власного успішного «Я» за короткий проміжок часу. При 
цьому слід пам'ятати, що інтерсуб'єктивний світ виникає лише в разі проекції власного «Я», коли суб'єкт в Іншому бачить себе, чи в разі ідентифікації, коли в собі знаходить Іншого. Тут публічний «знак» як окремий символізм $є$ більшою мірою випадковим: він виявляє логіку уявлення (репрезентації) несуб'єктного Іншого в ролі ініціатора суб'єктивності як самості. При цьому публічність як простір «між» не «розчиняється» остаточно в якійсь онтологічній основі, а $є$ підгрунтям для формування суспільного компромісу й консенсусу: «Тільки спів-участь у бутті інших істот відкриває сенс й підвалини власного буття» [1, с. 118].

\section{Література:} $353 \mathrm{c}$.

1. Апресян Р. Г. Идея морали и базовые нормативно-этические программы. М. : ИФ РАН, 1995.

2. Бауман 3. Текучая современность / пер. с англ. под ред. Ю. В. Асочакова. СПб. : Питер, 2008. $240 \mathrm{c}$.

3. Бодрийяр Ж. Символический обмен и смерть. М. : Добросвет, 2000. 387 с.

4. Бычков В. В. Эститика : учеб. М. : Гардарики, 2004. 556 с.

5. Газнюк Л. М. Соматичне буття персонального світу особистості. Х. : ХДАФК, 2003. 356 с.

6. История Красоты / пер. с итал. А. Сабашниковой под ред. У. Эко. М. : Слово, 2006. 440 с.

7. Косяк В. А. Экскурс в телесное жизневосприятие // Практична філософія. 2005. №2 (№16). C. $188-202$.

8. Крюковский Н. И. Логика красоты. Минск, 1965. С. 464.

9. Лосев А. Ф. История античной эстетики. Софисты. Сократ. Платон. М. : «Искусство», 1969. $\mathrm{T} 2.60 \mathrm{c}$.

10. Мартынов В. Ф. Философия красоты. Минск : ТетраСистемс, 1999. 336 с.

11. Плеснер $X$. Ступени органического и человек: Введение в философскую антропологию / пер. с нем. А. Г. Гаджикурбанова. М. : РОССПЭН, 2004. 368 с.

12. Сартр Ж.-П. Экзистенциализм - это гуманизм. Сумерки богов / сост. и общ. ред. А. А. Яковлева. М. : Политиздат, 1989. С. 319-345.

13. Татаркевич B. История шести понятий / пер. с польск. Б. Домбровского. М. : Дом интеллектуальной книги, 2003. 374 с.

14. Тед Чан. История твоей жизни. Тебе нравится, что ты видишь? / пер. А. Комаринец. Издательство : АСТ, Люкс , 2005. С. 337-389.

15. Флоренский П. А. Столп и утверждение истины. Приложение к журналу «Вопросы философии» : в 2 т. Т. 1 / АН СССР, Ин-т философии, Философское общество СССР ; вступ. ст. С. С. Хоружий. М. : Правда, 1990. 490 с.

16. Фромм Э. Иметь или быть? / пер. с англ. Э. М. Телятниковой. М. : АСТ, 2014. 314 с.

17. Blacking J. Towards an Anthropology of the Body. The Anthropology of the Body. London : Academic Press, 1977. Pp. 1-28.

18. Featherstone M. The Body in Consumer Culture. The Body: Social Process and Cultural Theory. London : Sage, 1991. Pp. 170-196. 


\section{Lyudmila Vasiljeva}

\section{A «PUBLIC PERSON» AS A DEMONSTRATIVE SYMBOL OF COMMUNICATIVE SPACE}

In this article, the exuberance of the multidimensional nature of the modern phenomenon of «public person» is conceptualized. The author argues that a person included in public life is a unique and open system. However, it is important to take into consideration that today's diversity of the human identity has to be actualized by the demonstrative function of the public environment and, by means of modern technologies and techniques it openly appeals to the formation of boundless desires and needs by creating the communicative environment of success and personal significance. Under these circumstances, the hidden identity of a modern person does not cause social interest, remaining obscure, and therefore it is not interesting to the mass «spectator». Moreover, in the context of the expansion of public space boundaries, a public person has an opportunity to easily demonstrate himself or herself as a meaningful «commodity», the one, that dispassionately and actively changes both physically and spiritually and adapts to the demanded models of personal presentation.

Existing scientific works on the phenomenon of publicity only emphasize the synthetic and ambivalent nature of the phenomenon of «public person», revealing the duality of this phenomenon through the combination of artificiality and naturalness. Among Ukrainian researchers one should note such scientists as S. Bordunov, M. Gryshchenko, O. Zulkevska, O. Zlobina, L. Malessa, A. Petrenko-Lisak, V. Sereda, I. Tishchenko, L. Radionov, etc.

An «everyone to see» lifestyle is a way of self-creation, authenticity obtaining, the approbation of different «Me» options through the excessive openness and demonstration. This is a peculiar way of liberation, mass rebellion. But can mass culture form the identity and uniqueness?

It is emphasized that the modern understanding of beauty in the public space is somewhat different from the classical canons of aesthetics and sometimes takes the most radical, artificial forms, which promotes to the aestheticization of the ugly cult of artificial beauty. At the same time, the concepts of beauty and fanciness should be distinguished. Since the notion of fanciness is based only on the formal characteristics of the object, determined by the trends of taste and fashion, the concept of beauty is based on the historical, social, national, cultural, religious, anthropic and other parameters of the subject of perception.

In the conditions of informational flood, a beautiful body becomes a mediator, which bounds the human «Me» with the social and public environment, shapes an image of a person. The modern actualization of a body is an actualization of its demarcation, in which numerous labels and signs dismember it as a given, and reconstructing it as a structural 
material for the sign exchange. In this way, the body with the mark differs from the one without. The socially marked part of the body, on the one hand, comes to the fore as a pathetic exhibit, and on the other hand, it is a testimony of a hidden symbolic content, which must be necessarily recognized by the publicly. It is precisely the reputation, not the image, that has to come to the fore and form the knowledge about the person and its publicity, but not the demonstrative image-publicity, which forms a figurative mosaic of self-conceived identity with putting it to everyone's judge. It should be remembered that an intersubjective world arises only in the case of the projection of own «Me», when the subject sees himself or herself in the Other, or in the case of identification, when finds someone Other in himself or herself. Here, the public «sign» as a separate symbolism is random: it manifests the logic of representation of the non-subjective Other as the initiator of subjectivity as a selfness. At the same time, publicity as space «between» does not completely «dissolve» in some ontological basis, but is the basis for the formation of a public compromise and consensus: «only co-participation in the existence of other beings opens the meaning and foundations of self-existence».

Keywords: publicity, corporeality, tolerance, "public person», body, image, reputation, the self, public existence.

\section{Людмила Васильєва}

\section{«ЛЮДИНА ПУБЛІЧНА» ЯК ДЕМОСТРАТИВНИЙ СИМВОЛ КОМУНІКАТИВНОГО ПРОСТОРУ}

У статті осмислено буттєвість багатовимірної природи сучасного феномена «людини публічної». Доведено, що людина, залучена до публічного життя, $\epsilon$ відкритою самобутньою системою. При цьому значним $є$ те, що самобутність людської самості натепер першочергово має актуалізувати демонстративною функцією публічного середовища й через новітні техніки й технології відкрито апелювати до формування безмежних людських бажань і потреб, створюючи тотальне комунікативне середовище успішності й особистісної значущості. За таких умов прихована самобутність сучасної людини не викликає соціального інтересу, залишаючись не зрозумілою, а значить, і не цікавою масовому «глядачу». Крім того, людина публічна в умовах розширення меж публічного простору повсякчас має можливість легко демонструвати себе як значущий «товар», безпристрасно й активно змінюючи себе як на фізичному, так i на духовному рівнях, адаптуючись до потрібних публічності моделей особистої презентації.

Наявні наукові роботи щодо феномена публічності лише підкреслюють 
синтетичність й амбівалентність характеристик феномена «людини публічної», виявляючи дуальність цього явища через поєднання штучності й природності. Серед українських дослідників слід відзначити С. Бордунову, М. Грищенко, О. Жулькевську, О. Злобіну, Л. Малеса, А. Петренко-Лисак, В. Середу, І. Тищенко, Л. Радіонову та ін.

Стиль життя «на очах» - це спосіб самотворення, набуття автентичності, апробації різних варіантів власного «Я» через надмірну відкритість й демонстративність. Це своєрідний спосіб звільнення, масового бунту. Але чи здатна масовість формувати самість, ідентичність й унікальність?

Підкреслено, що сучасне розуміння краси в публічному просторі дещо відрізняється від класичних канонів естетики, набирає іноді найрадикальніших, штучних форми, що сприяє естетизації потворного культу штучної краси. При цьому варто принципово відрізняти поняття краси від красивості, оскільки поняття красивості спирається тільки на систему поверхових формальних характеристик об’єкта, детермінованих віяннями смаку й моди, на сприйняття ж краси впливають історичні, соціальні, національні, культурні, релігійні, антропні й ін. параметри суб’єкта сприйняття.

У сучасних умовах інформаційної перенасиченості гарне тіло стає посередником, який пов'язує людське «Я» 3 соціально-публічним середовищем соціуму, формує образ, імідж людини. Сучасна актуалізація тіла - це актуалізація його демаркації, у якій низка позначок і знаків розчленовують його як даність, реконструюючи як структурний матеріал для знакового обміну. У такий спосіб тіло 3 позначкою відрізняється від тіла без позначки. Соціально маркована частина тіла, 3 одного боку, висувається на перший план як пафосний експонат демонстрації, а 3 другого - є свідченням символічного прихованого змісту, який обов'язково має бути визнаний публічно. Тут саме репутація, а не імідж має виходити на перший план, формувати знання про людину та іiї публічність, а не демонстративна іміджпублічність, що формує образну мозаїку надуманої власної ідентичності 3 виставлянням іiі на суд соціального оточення та $є$ простим й зручним засобом побудови бажаної особистісної ідентифікації власного «Я» за досить короткий час. При цьому слід пам'ятати, що інтерсуб'єктивний світ виникає лише в разі проекції власного «Я», коли суб'єкт в Іншому бачить себе, чи в разі ідентифікації, коли в собі знаходить Іншого. Тут публічний «знак» як окремий символізм є випадковим: він виявляє логіку уявлення (репрезентації) несуб'єктного Іншого в ролі ініціатора суб’ єктивності як самості. При цьому публічність як простір «між» не «розчиняється» остаточно у якійсь онтологічній основі, а є підгрунтям для формування суспільного компромісу й консенсусу: «Тільки спів-участь у бутті інших істот відкриває сенс й підвалини власного буття».

Ключові слова: публічність, тілесність, толерантність, «людина публічна», 
тіло, імідж, репутащія, самість, публічне буття.

Vasiljeva Lyudmila - PhD in Philosophy, Associate Professor of the Department of Law of National Aerospace University "KhAI".

Васильсва Людмила Анатоліївна - кандидат філософських наук, доцент, доцент кафедри права гуманітарного факультету Національного аерокосмічного університету ім. М.Є. Жуковського «ХАI».

e-mail:

Надійшла до редакції 13.11.2018. Розглянута на редколегії 18.12.2018.

\section{Рецензенти:}

Доктор філософських наук, професор, декан гуманітарного факультету Національного аерокосмічного університету ім. М.С. Жуковського «ХАI» Копилов В.О.

Доктор філософських наук, професор, професор кафедри філософії Харківського національного університету Повітряних Сил імені Івана Кожедуба Панфілов О.Ю. 